\title{
Studies on Some Major and Trace Metals in Smoked and Oven- Dried Fish
}

\author{
AKO, P A; SALIHU, S O \\ Department of Chemistry, Federal University of Technology, Minna, Nigeria.
}

\begin{abstract}
The mineral ( $\mathrm{Li}, \mathrm{Na}, \mathrm{K}, \mathrm{Ca}, \mathrm{Mg}, \mathrm{Fe}, \mathrm{Cu}, \mathrm{Mn}, \mathrm{Zn}$ and $\mathrm{Pb}$ ) composition of each of five species of fish, including Sarotherodon galilaues, Cyprinus carpio, Clarias gariepinus, Sardinella spp. and Labeo spp. Was determined in samples previously dried, either by traditional smoking method, or in laboratory oven, to gain knowledge of the quality and acceptability of the smoked products. The samples were brought from markets in Minna metropolis, Niger State of Nigeria. Portions of the meals of whole fish were digested in a nitric acid-hydrogen peroxideperechloric acid (3:11) mixture and the digests were analysed spectrophotometrically. The concentration of lead was lowest in both smoked and oven-dried specimens with mean values ranging from 0.46 to $1.16 \mathrm{mg} / \mathrm{kg}$ and 0.54 to $0.76 \mathrm{mg} / \mathrm{kg}$, respectively, while calcium with ranges of 592.98 to $7553.55 \mathrm{mg} / \mathrm{kg}$ and 498.65 to $6460.85 \mathrm{mg} / \mathrm{kg}$ was highest. Comparative studies showed that no significant differences existed between the mineral contents of the samples from the two drying methods, except in the few cases of lithium in S. galilaeus, zinc in C. gariepinus, copper and manganese in both Cyprinus carpio, and Sardinell spp, and lead in S. galilaues. Nonetheless, the smoked samples were consistently richer in their mineral content, suggesting the need for chemical examination of products of this drying method. @JASEM
\end{abstract}

Fish production is a major industry in those parts of Nigeria where reverine settlements are established. These communities produce a substantial percentage of the protein needs of the population of the surrounding villages and towns through fishing. In Niger State, communities located along the banks of Shiroro and Kainji rivers, witness great fishing activity throughout the year. However, the fishermen and largely of the peasant class with limited exposure to modern fish preservation technology. Thus, fish being a highly perishable food, whether fishing is practiced on a commercial scale or for domestic consumption of the catch, smoking is the preferred cheap method of preventing its spoilage. This is carried out over smouldering wood, sawdust or other local sources of energy using traditional kilns constructed with locally sourced materials.

It is instructive that the design of the kiln notwithstanding, operations involved in the smoking of fish are similar and the method has the effect of imparting a pleasant flavour to the product besides the preservative effect of the smoke itself (Burgress et al, 1965; Tull, 1997). But smoked fish being a foreign exchange earner for Nigeria, researchers are concerned about the quality of products. This was apparent from the investors forum that was jointly organized recently by the Nigerian Institute for Oceanography and Marine Research and the Raw Materials Research and Development Council, where participants called for better handling, processing and packaging of products to meet the required standards set by authorities in the countries of export (Oyeleye, 2003). Nevertheless, the pre-treatment of fish for smoking, packaging materials, and storage conditions may differ widely, so that fish obtained in the market have tremendously variable quality. Buckle et al
(1998) listed distribution, transport and wholesaling as sources of contamination of fish. Good hygienic conditions, therefore, could enhance fish quality, but it seems that not much can be done to exclude contamination by minerals. These are introduced by the smoke in addition to those absorbed through ingestion of contaminated food or through the gills from the surrounding water and concentrations could reach toxic levels. On the other hand, nutritional losses resulting from preservation processes have been reported (Burgress, 1975). Incidences such as these are likely to affect product quality adversely. Thus, as dried fish continues to occupy its important place as a delicacy in the dishes of Nigerians and technologies and processes employed in drying remain underdeveloped, the dangers of possible contamination of smoked products need to be brought to the fore.

It was, therefore, important and necessary to conduct this study to determine the concentrations of some major and trace elements in fish dried traditionally by smoking and compare the levels with those of fresh samples of the same species that were dried in laboratory oven.

\section{MATERIALS AND METHODS}

The fish samples for the study included Sarotherodon galilaeus, Sardinell spp., Labeo spp., Cyprinus carpio, and Clarias gariepinus. Both the smoked and fresh samples of the different species were brought from markets within Minnna metropolis, Niger State of Nigeria, at bimonthly intervals for three consecutive months during the wet season. Care was taken, especially in the case of the pre-dried samples to avoid including damaged ones and also, buying from the same retailer. Three medium sized samples

*Corresbonding author 
represented the batch for each species during each sampling exercise. The samples were conveyed to the laboratory in newly purchased polythene bags. Fresh samples were washed with de-ionised distilled water to remove slime and/or ice, drained and water removed with tissue paper. They were then dried on white cardboard sheets in the laboratory oven at an initial temperature of $70^{\circ} \mathrm{C}$ which was increased to about $105^{\circ} \mathrm{C}$ after 3 hours. Heating was continued for another 12 hours at this temperature. after allowing to cool overnight, the samples were further heated for 8 hours at this temperature, cooled and then exposed to ambient laboratory temperatures to air-dry for three days. The pre-dried samples were also similarly exposed. Each whole fish was carefully broken in a porcelain mortar and ground. In some cases, the head, bones and tail were separately crushed and ground before including the fleshy part. The meal was then packed into a clean dry screw cap bottle and stored in a freezer pending chemical analysis.

About 2.5g of the samples already dried to constant weight was weighed and mixed with $20 \mathrm{~cm}^{3}$ of nitric acid - hydrogen peroxide (3:1) in a $100 \mathrm{~cm}^{3}$ digestion flask, swirled to ensure proper dispersion and left to stand for 48 hours at room temperature to digest. The mixture was then refluxed on a heating mantle until fuming ceased. $5 \mathrm{~cm}^{3}$ of perchloric acid was added and further refluxed for 30 minutes. After cooling, the resulting digest was made up to $100 \mathrm{~cm}^{3}$ with de-ionised distilled water. Lithium, sodium potassium and calcium were measured with a JENWAY PEP7 flame photometer. Magnesium, lead, iron, copper, manganese and zinc were on the other hand determined with an atomic absorption spectrophotometer (Philips PU 9100).

\section{RESULTS AND DISCUSSION}

The mineral content $(\mathrm{mg} / \mathrm{kg})$ of the five species of fish analysed are presented in Table 1. Except in the case of potassium where the same species (Sardinella spp and Labeo spp) have the lowest and highest concentrations respectively in both smoked and ovendried specimens, no such correspondence was found in respect of other elements or samples. Among the major elements ( $\mathrm{Na}, \mathrm{K}, \mathrm{Mg}$, and $\mathrm{Ca}$ ), no well-defined order of magnitude within the same specie of fish was evident. This is contrary to the report of Oladimeji and Sadiku (1991) where the decreasing order $\mathrm{K}>\mathrm{Na}>\mathrm{Mg}>\mathrm{Ca}$ was found in the edible muscle tissues of S.galilaues. Lates niloticus and synodontis schall. Teeny et al (1984) reported a similar decreasing order for several other species of fish. However, the order of magnitude of these elements reported by Kirchgessner and Schwart (1986) was $\mathrm{Ca}>\mathrm{K}>\mathrm{Na}>\mathrm{Mg}$. With regard to the trace elements some appreciable degree of consistency was evident generally, producing the order $\mathrm{Fe}>\mathrm{Mn}>\mathrm{Li}>\mathrm{Zn}>\mathrm{Cu}>\mathrm{pb}$, especially in the traditionally smoke dried samples.

In the report of Teeny et al (1984), lithium was lowest while zinc was found to be highest in concentration among the elements determined. Of importance in this respect too were the findings of Khan et al (1987) which did not exhibit any definite order in the magnitude of the elements in the respective species of fish studies. Other researchers have mae similar observations with regard to the lack of agreement of different reports in the order of magnitude of mineral content of a given pieces of fish.

Table 1: Mean concentration (mg/kg) of major and trace metals determined in five species of fish dried by traditional smoking and in laboratory oven.

\begin{tabular}{|c|c|c|c|c|c|c|c|c|c|c|}
\hline $\begin{array}{l}\text { Fish } \\
\text { sample/Metal }\end{array}$ & $\mathrm{Li}$ & $\mathrm{Na}$ & K & $\mathrm{Ca}$ & $\mathrm{Mg}$ & $\mathrm{Pb}$ & $\mathrm{Fe}$ & $\mathrm{Cu}$ & Mn & $\mathrm{Zn}$ \\
\hline \multicolumn{11}{|l|}{ Smoked } \\
\hline S. galilaeus & 233.1 & 3320.4 & 4116.8 & 7026.5 & 1671.0 & 0.46 & 565.5 & 31.4 & 845.6 & 99.9 \\
\hline Cyrpinus spp & 215.5 & 4580.2 & 4089.8 & 529.9 & 1512.2 & 0.73 & 727.5 & 8.6 & 272.9 & 60.3 \\
\hline c.gariepinus & 195.9 & 3084.6 & 3884.6 & 7553.5 & 1797.8 & 0.56 & 804.5 & 5.2 & 510.7 & 62.0 \\
\hline Sadinella spp & 109.8 & 4035.2 & 3491.2 & 702.0 & 1549.2 & 0.75 & 720.9 & 7.0 & 291.2 & 65.7 \\
\hline Labeo carpio & 155.4 & 3206.9 & 4190.8 & 3700.4 & 1804.7 & 1.16 & 490.2 & 8.3 & 437.2 & 72.7 \\
\hline \multicolumn{11}{|l|}{ Oven-dried } \\
\hline S. galilaeus & 157.2 & 3089.4 & 3764.2 & 5653.9 & 1606.5 & 0.76 & 621.6 & 11.0 & 796.6 & 79.0 \\
\hline Сyrpinus spp & 119.4 & 4064.5 & 3823.9 & 590.2 & 1446.2 & 0.72 & 476.4 & 6.7 & 517.2 & 59.6 \\
\hline C.gariepinus & 175.6 & 2940.3 & 3788.4 & 6460.8 & 1940.3 & 0.66 & 606.6 & 4.6 & 255.8 & 32.6 \\
\hline Sadinella spp & 108.9 & 3304.8 & 3547.6 & 498.6 & 1316.4 & 0.54 & 553.2 & 4.2 & 218.4 & 52.9 \\
\hline Labep carpio & 137.1 & 2560.3 & 4009.8 & 2908.9 & 1741.0 & 0.59 & 387.2 & 6.5 & 287.7 & 62.9 \\
\hline
\end{tabular}

In the present study, the two groups of samples of fish (pre-dried and fresh) were exposed to the same sources of possible contamination after the fresh ones had been dried in the laboratory oven. It is also worthy of mention that the method of destruction of organic matter by wet oxidation in the analysis of biological (biochemical) materials that was employed in this work gives good recoveries of not less than 94 percent (Gorush 1970, Teeny et al, 1984). Loss of elements from or contamination of one sample with 
respect to the other, therefore, cannot be a valid reason in explaining the observed variation in the result of the individual mineral contents of supposedly similar (if not same) samples.

It is pertinent at this point to draw attention to the observation that the nutritional composition of fish muscle varies both from species to species and within species, from one season to another (Burgress, 1975). Perhaps, additional explanation may be sought from the important and possible contribution of environmental factors to the concentration of metal in fish. This view is supported by the findings of Window et al (1987) and Khan et al (1987), which showed that variations in the concentrations of elements from one sample of fish to another was due to the chemical forms of the elements and their concentrations in the local environment. Microbiological activities in the marine environment, feeding habits and the age of the fish, have also been implicated by these and other authors. Even if similar physiology, habitat and feeding habits were assumed for sub-specific population of fish specie, the former authors reported that differences in their metal concentrations in the two environments would be reflected. The findings of Ibok et al (1989) are in agreement with this thinking.

Furthermore, the view is held (Kirchgessner and Schwarz, (1986) that within a specie of fish, mineral retention depends mainly on the feed and feeding rate, interaction with the environmental water and the total energy supply. Nonetheless, Windom et al (1987) concluded that although anthropogenic inputs might elevate the concentration of metals in the environment, their accumulation in the muscle tissues of fish might be regulated biochemically to exclude toxic concentrations. Perhaps[s it is also pertinent to draw attention to the absence of sample size (weight) in the data of the present study. Certainly, this parameter is important in explaining the different metal concentrations determined in the samples.

In the analysis of S.galilaeus muscles, Oladimejo and Sadiku (1991) reported mean values of 1117.00, 565.33, and 96.53. 403.80, 3.53 and 9.21mg/100g sample for $\mathrm{K}, \mathrm{Na}, \mathrm{Mg}, \mathrm{Ca}, \mathrm{Zn}$ and Fe respectively during the wet season, which corresponded to the period during which this study, especially the sampling, was conducted. Corresponding mean values of the respective elements in the same specie of fish in this report are 4116,89, 3320.42, 1671.05, 7026.57, 99.99 and $565.59 \mathrm{mg} / \mathrm{kg}$ for traditionally smoked-dried specimens, while the oven dried specimens are 3764.20, 3089.45, 1606.52, 5653.93, 79.06 and $621.61 \mathrm{mg} / \mathrm{kg}$ respectively. The wide differences observed between the results of the two studies, with respect to the concentrations of magnesium, calcium, zinc and iron, which are higher in value in the present report, can readily be understood in terms of the fact that whole fish samples, as opposed to edible muscles only, as is the case in the previous study, were analyzed. But while these results were expected, no equally tangible reason is immediately available to explain the wide disparity between the results of the earlier report and those of the present one with respect to the concentration of sodium and potassium in S.galilaeus. The problem is not helped either by the apparent dearth of information on the distribution of metals in different parts of species of this. Nonetheless, Teeny et al (1984) found no significant difference between the levels of certain elements including sodium and potassium in the nape and tail sections of fish samples. Furthermore, Prasad and Veeraiah (2002), indicated that although exposure to chemical pollutants elicits molecular and biochemical changes in fish, the severity of the protein depletion caused by cypermethrin in their study differed significantly from one organ or tissue to the other, and according to the duration of the exposure to the chemical concerned. Davidson et al (1979) had earlier reported the differential concentration of elements in organs and tissue for the human body. Therefore, it may be suggested from the foregoing that particular elements tend to concentrate more in one part of fish at the expense of others. Consequently, the use of whole fish in the determination of mineral content may tend to have a diluting effect on "favoured" parts and may, therefore, account for the differenkes $P$ bs ardidal, $S O$ between the results of the two studies.

Comparing the results of the mineral contents of the traditionally smoke-dried samples with those of the oven dried ones (Table 2), it is clear that no contamination, with regard to the major elements, of the former samples may have occurred in view of the absence of significant differences. Similarly, except in the few cases of lithium, in S. galilaeus, zinc in C. gariepinus, copper and manganese in both Cyprinus carpio and Sardinella spp., the differences in trace element content were non-significant $(\mathrm{P}=0.5)$. Lead in S.galilaeus also indicated some significant difference $(p=0.01)$. Implications of the general absence of significant difference between the levels of metals in fish obtained from the two drying methods investigated are three-fold. First, is the support it lends to the claim that smoked fish were rarely taken through a salting stage prior to smoking (personal communication). Second, if any loss of metal to fish from the material on which the samples were laid for smoking was envisaged, such losses could only have been minimal in magnitude. Third, and important too, is the suggestion that smoke and ash may have made no substantial contribution to the fish mineral content during the processing. The traditionally dried samples were, nonetheless, 
generally richer in all the elements studies. The exception observed for lead in S.galulaeus and C.gariepinus was unexpected, but again, it may sound reasonable to direct attention to the influence of habitat and environment of fish on its metal concentration. Worthy of note too is the presence of this element in all the samples. Nwaedozie (1998) reported similar findings in fish caught from Kaduna
River that is a likely source of some of the samples of the present study. The former, having been classified as a major toxic element (Merill et al, 2001), its presence in fish should be of great concern. Regrettably, however, critical levels of elements in fish are lacking in the literature, and therefore do not permit recommendations and statements on specific suspected contamination, if any.

Table 2: Comparison of mean concentration of fish dried traditionally by smoking and in laboratory oven.

\begin{tabular}{llllll}
\hline $\begin{array}{l}\text { Metal/fish } \\
\text { Sample }\end{array}$ & S. galilaues & $\begin{array}{l}\text { Cyprinus } \\
\text { Carpio }\end{array}$ & C.gariepinus & Sadinella spp & Labeo spp. \\
\hline $\mathrm{Li}$ & $10.80^{*}$ & 1.11 & 1.59 & 0.22 & 1.61 \\
$\mathrm{Na}$ & 0.91 & 1.05 & 1.18 & 1.58 & 1.08 \\
$\mathrm{~K}$ & 1.83 & 1.70 & 0.58 & 1.33 & 0.91 \\
$\mathrm{Ca}$ & 1.80 & 0.08 & 1.46 & 1.61 & 1.44 \\
$\mathrm{Mg}$ & 0.35 & 0.93 & -0.69 & 0.92 & 0.38 \\
$\mathrm{~Pb}$ & $-2.5 * *$ & 0.07 & -0.81 & 0.78 & 0.90 \\
$\mathrm{Iron}$ & -0.28 & 1.18 & 1.27 & 0.85 & 0.53 \\
$\mathrm{Cu}$ & 0.89 & 2.24 & 0.54 & $2.87^{*}$ & 1.38 \\
$\mathrm{Mn}$ & 0.30 & $-2.44^{*}$ & 1.46 & $4.18^{*}$ & 1.77 \\
$\mathrm{Zn}$ & 2.15 & 0.14 & $3.94^{*}$ & 1.28 & 0.93 \\
\hline \multicolumn{5}{r}{} \\
\end{tabular}

In spite of this apparent difficulty, a comment on the observed absence of any evidence of salting of the smoked samples of fish may be necessary. Although the omission of the salt treatment will no doubt reduce the resistance of the product to microbiological, enzymatic ad chemical deteriorative changes, it nevertheless, may lead to its acceptance by a lager number of consumers. It is also clear from this investigation that smoking as a method of fish preservation may raise the mineral composition of the product to levels that are either beneficial or toxic to humans. Therefore, product quality and acceptability need to be assessed on the basis of not only the perceivable physical properties such as texture, odour and flavour, but also by the mineral composition. The method of smoking and duration of exposure to the smoke have been identified as important factors that affect product quality and acceptability (Indrasena et al, 2000). In Nigeria, the smoked fish industry, which is dominated by peasant fish farmers, is presently confronted with the problem of underdevelopment and use of diverse materials and methods. The findings of this study call for the need to standardize procedures and methods to enhance the quality and consequently, the export potential of the products.

Finally, Niger state is essentially an agrarian state where intensive crop production is practices. Contamination of bodies of water (rivers, lakes and ponds) by wash off from farmlands is, therefore, not an uncommon feature. It is also known that the Shiroro Dam in the eastern part of the state derives its water from River Kaduna which receives a high concentration of industrial effluents. As earlier suggested, metabolic processes occurring in fish may concentrate individual elements in the water and food in the surrounding environment in certain organs and tissues. Thus, in addition to the factors already mentioned, the contribution of the different aquatic environments is important in accounting for the variations observed in the mineral contents of the fish samples employed for the study.

\section{REFERENCES}

Buckel K.A; Souness RA; Putro, S; Wuttijumong, P (1998). In: CC. Seow (Edi). Food Preservation by Moisture Control. Elsevier Applied Science Publishers Ltd. U.K. pp103-115.

Burgress GHO (1975). Increasing the direct consumption of fish. In: W W Pirie (Edi). Food Protein Sources. International Biological Programme 4. Cambridge University Press. Cambridge. Pp 187-200.

Burgress, G H O; Cutting, C L; Lovern, J A; Waterman, J J (1965). Fish Handling and Processing. Tory Research Station, Ministry of Technology, Edinburg, Her Majesty's Stationary Office, London. Pp 70-101.

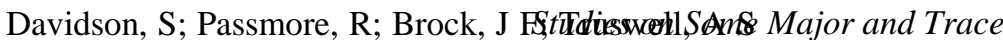
(1979). Human Nurtriction and Dietitics. $7^{\text {th }}$ Ed. Churchill Licingstone. New York. Pp 90-116. 
Gorsuch, T T (1970). The Destruction of Organic Matter. Pergamon Press. New York. Pp 55-133.

Indranesa, W M; Hansen, L T; Gill, T A (2000). Effect of cold-smoking and drying on the textural properties of farmed Atlantic Salmon (Salmosalar0. J. Aquatic Food. Product Tech. 9(1): 47-64.

Ibok, U J; Udosen, E D; Udoidiong, O M (1989). Heavy metals in fishes from some streams in Ikot Ekpene area of Nigeria. Nig. J. Tech. Res. 1:61-68.

Khan, A H; Ali, M; Biaswas, S K; Hadi, D A (1987). Trace elements in marine fish from the Bay of Bengal. The Science of the Total Environment. 61:12-130.

Kirchgessner, M; Schwarz, F J (1986). Mineral Content (major and trace elements) of carp (Cyprinus carpio L.) fed with different protein and energy supplies. Aquaculture. 54:3-9.

Merril, J C; Morton, J J P; Soil $\backslash$ eau, S D (2001). Metals. In: A W Hayes (Edi). Principles and Methods of Toxicology. $4^{\text {th }}$ ed. Taylor and Francis. Philadelphia. Pp 667-669.
Oladimeji, A A; Sadiku, SOE (1991). Mineral constituents of Lates niloticus (L) Synodontis schall (Broch and Schneider) and Sarotherodon galilaeus (Trewavas) from Zaria (Nigeria) Dam. J. Anim. Prod. Res. 11:45-52.

Oyeleye, O. (2003). Export potentials of smoked fish trade in Nigeria. The Guardian 19(8916): 27. Guardian Newspapers, Lagos, Nigeria.

Prasad, M R D; Veeraiah, K (2002). Effect of cypermethric on protein metabolism of the fish Labeo rohita. Bull. Pure and Appl. Sci. 21A(1): 27-32.

Teeny, F M: Gauglitz, E J(Jr.); Hall, A S; Houle, C R (1984). Mineral composition of the edible muscle tissue of seven species of fish from the Northeast Pacific. J. Agric. Food Chem. 32(4): 852-855.

Tull. A (1997). Food and Nutrition. $2^{\text {nd }}$. Ed. Oxford University Press. Oxford U.K. pp. 104109.

Windom, H; Stein, D; Sheldon, R: Smith, R Jr. (1987). Comparison of trace metal concentrations in muscle of a benthopelagic fish (Coryphaenoides armatus) from the Atlantic and Pacific oceans. Deep Sea Research. 34(2): 213220.
Nwaedozie, J M (1998). The determination of heavy metal pollutants in fish samples from River Kaduna J. Chem. Soc. Nigeria. 23:21-23. 